\title{
CARDIOVASCULAR COMORBIDITIES IN HOSPITALIZED PSYCHIATRIC PATIENTS WITH DIAGNOSES OF SCHIZOPHRENIC AND AFFECTIVE DISORDERS
}

\section{AUTHORS}

Djokić Pješčić Katarina ${ }^{1,2}$, Gutović Jasmina ${ }^{1}$, Tesić Jelica ${ }^{1}$, Dukić Dejanović Slavica ${ }^{1,3}$, Grbić Igor $^{1,2}$, Cvetković Jovana ${ }^{2}$

${ }^{1}$ Clinic for psychiatric disorders "Dr Laza Lazarević”, Belgrade, Serbia

${ }^{2}$ Faculty of Medicine, University of Pristina, Kosovska Mitrovica, Serbia

${ }^{3}$ Faculty of Medicine, University of Kragujevac, Serbia

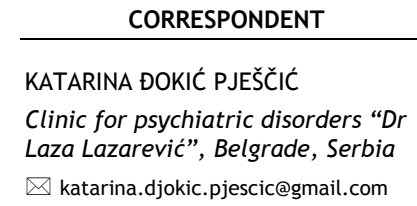

\section{ABSTRACT}

A cardiovascular comorbidity (CVC) in psychiatric patients represents a simultaneous occurrence of a cardiovascular and a mental illness in the same patient regardless of the order of occurrence or of the cause and effect relationship that conjoins them. The objective was to determine the frequency and sort of the CVC in previously hospitalized patients with diagnoses of schizophrenic and affective disorders along with the differences in distribution of said disorders between the two groups of patients. Design-wise this is a retrospective study of intersections. It is based on the analytics of medical data (the history of disease along with the internal medicine consultant reviews) of the hospitalized patients in the Clinic for psychiatric disorders "Dr. Laza Lazarević" in Belgrade during the period between November 2014 and February 2015. Patients who were involved were older than 18 and they had diagnoses of schizophrenic disorders (F20-F29) and affective disorders (F30-F39), according to diagnostic criteria in the International classification of diseases 10 (ICD-10). CVC which were previously diagnosed or registered during the examination we separated into the following groups according to ICD-10: hypertension (HTA) I10, cardiac arrhythmia (CA) 147-I49, chronic cardiomyopathy (CMP) 142-143 and ischemic heart disease (IHD) 120-125. The two groups of patients were analyzed according with socio-demographic characteristics (gender and age range) and CVC diagnosed according to MKB-10 classification. CVC were registered in $66 \%$ of the patients diagnosed with schizophrenia and $34 \%$ of the patients with affective disorders. Hypertension was most common in both groups of patients following with cardiac arrhythmia. Cardiac arrhythmias were statistically significantly more common in patients diagnosed with schizophrenic disorders $(p<0.001)$ compared to patients with affective disorders. The frequency of hypertension, ischemic heart disease and chronic cardiomyopathy rises with age in both groups of patients. The results of this research confirm a high degree of CVC in hospitalized patients with diagnoses of schizophrenic and affective disorders (especially cardiac arrhythmia and hypertension). A multidisciplinary team is the key for diagnosing and monitoring patients with schizophrenic and affective diseases in both primary and secondary preventions.

Key words: comorbidity, cardiovascular diseases, schizophrenic disorders, affective disorders.

\section{INTRODUCTION}

Numerous studies have shown that the mortality of patients with psychiatric disorders is two to three times higher compared to the general population [1]. People who suffer from psychiatric disorders live 15-25 years less than the general population, mostly due to the heightened mortality rate from cardiovascular diseases [2].

Cardiovascular comorbidities (CVC) in psychiatric patients represent a simultaneous occurrence of cardiovascular and mental disorders in the same patient regardless of the order of occurrence or the cause and effect relationship that conjoins them [3].

While the mortality rate from cardiovascular diseases decreases worldwide, patients suffering from disorders within the schizophrenic spectrum show a rising mortality rate, mostly due to the under-recognition of risk factors [4]. Important factors in patients who suffer from diseases within the schizophrenic spectrum that contribute to the occurrence of CVC follow a basic psychiatric disorder and are related to specific life habits, a poor diet, a deficiency in physical activity, smoking and the substances abuse. The latest studies suggest the existence of intersections between pathophysiological mechanisms in the occurence of schizophrenia and cardiovascular diseases $[5,6]$

The effects of antipsychotics should not be ignored when calculating cardiovascular risk factors. Undesired cardiovascular effects of psychotropic drugs are common and potentially very harmful [7]. Atypical antipsychotics can trigger unexpected cardiovascular effects such as arrhythmia, abnormality in blood pressure, congestive 
heart insufficiency, myocarditis, even a sudden cardiac death [8].

Likewise, the results in numerous studies show that these patients have limited access to primary prevention of cardiovascular diseases on the primary level of health care [9]. Patients with bipolar disorders and who already are diagnosed with CVC (hypertension and ischemic heart disease) receive poorer treatment compared to the general public [10].

\section{STUDY OBJECTIVE}

The objective of this study was to determine the frequency and type of CVC in hospitalized patients with diagnoses that include schizophrenic and affective disorders and to check the differences in occurrence between the two groups of patients.

\section{MATHERIAL AND METHODS}

Design-wise, this is a retrospective study of intersections. It is based on the analyses of medical data (the history of disease along with internist reviews) of hospitalized patients from The Clinic for psychiatric disorders "Dr. Laza Lazarevic" in Belgrade during the period between November 2014 and February 2015. The criteria consist of: diagnostic category F20-F29 (schizophrenic disorders) and F30-F39 (affective disorders), according to diagnostic criteria in the International classification of diseases 10 (ICD-10), as well as the age range of $18+$.

The differences in the two groups of patients were analyzed in accordance with socio-demographic charac- teristics (gender and age) and CVC were diagnosed in accordance with MKB-10 classification. CVC which were previously diagnosed or registered during the examination we separated into the following groups according to ICD-10: hypertension (HTA) I10, cardiac arrhythmia (CA) 147-149, chronic cardiomyopathy (CMP) 142-143 and ischemic heart disease (IHD) 120-125.

For the analysis of primary data descriptive methods and methods for testing statistical hypotheses were used. From descriptive statistical methods were used measure of central tendency (mean), a measure of variability (standard deviation), and relative numbers. Statistical hypotheses were tested by Hi-square test and Fisher exact test. For statistical analysis we used the statistical software package SPSS 21 . The criterion for statistical significance was $P<0.05$.

\section{RESULTS}

During the observation time period, the Clinic for psychiatric disorders "Dr. Laza Lazarevic" in Belgrade, has hospitalized a total of 421 psychiatric patients with diagnoses that include schizophrenic and affective disorders. The characteristics of the patients are presented in table 1.

The entire sample consisted of $40,9 \%$ male and $59,1 \%$ female patients. The average age of the patients was $48,54 \pm 12,87$. In the group of patients suffering from psychiatric disorders, most patients had the F29 diagnosis - unspecified inorganic psychosis $(19,5 \%)$, following with F20 - schizophrenia $(18,3 \%)$. The group of patients suffering from affective disorders, most patients had the F32 diagnosis - a depressive episode $(18,1 \%)$.

Table 1. Characteristics of patients

\begin{tabular}{|c|c|}
\hline Variable & $\mathrm{N}=421$ \\
\hline \multicolumn{2}{|l|}{ Gender, n (\%) } \\
\hline Male & $172(40.9)$ \\
\hline Female & $249(59.1)$ \\
\hline Áge, meantsd & $48.54 \pm 12.87$ \\
\hline \multicolumn{2}{|l|}{ F category, $n(\%)$} \\
\hline Schizophrenic disorders & $278(66)$ \\
\hline Affective disorders & $143(34)$ \\
\hline \multicolumn{2}{|l|}{ F diagnosis, n (\%) } \\
\hline F20 & $77(18.3)$ \\
\hline F22 & $34(8.1)$ \\
\hline F23 & $48(11.4)$ \\
\hline F25 & $37(8.8)$ \\
\hline F29 & $82(19.5)$ \\
\hline F30 & $1(0.2)$ \\
\hline F31 & $37(8.8)$ \\
\hline F32 & $76(18.1)$ \\
\hline F33 & $29(6.9)$ \\
\hline$\overline{C M} \mathrm{P}^{\mathrm{a}}, \mathrm{n}(\mathrm{\%})$ & $10(2.4)$ \\
\hline $\mathrm{CA} \bar{a}^{\mathrm{a}}, \mathrm{n}(\%)$ & $83(19.7)$ \\
\hline$I H D^{a}, n(\%)$ & $29(6.9)$ \\
\hline HTA & $226(53.7)$ \\
\hline
\end{tabular}

CMP - chronic cardiomyopathy (I42-143); HTA - hypertension (I10), CA - cardiac arrhythmia (I47-I49); IHD ischemic heart disease (I20-125)

Table 2. Distribution of schizophrenic and affective disorder by gender

\begin{tabular}{|c|c|c|c|c|c|c|}
\hline & \multicolumn{2}{|c|}{ Schizophrenic disorders } & \multicolumn{2}{|c|}{ Affective disorders } & \multicolumn{2}{|c|}{ Total } \\
\hline & n & $\%$ & n & $\%$ & $n$ & $\%$ \\
\hline Men & 111 & 39.9 & 61 & 42.7 & $172^{-}$ & 40.9 \\
\hline Women & 167 & 60.1 & $82^{-1}$ & 57.3 & $249^{-}$ & 59.1 \\
\hline Total & 278 & 100 & 143 & $100^{-}$ & $4 \overline{2} \overline{1}^{-}$ & 100 \\
\hline
\end{tabular}


A statistically significant difference in distribution of occurrences between schizophrenic and affective disorders according to gender was non-existent (chi square $=0,291, \mathrm{DF}=1, \mathrm{p}=0.590$ ) (Table 2). However, a statistically significant difference in distribution of occurrences between schizophrenic and affective disorders according to patients age groups was present (chi square $=20,080, D F=4, p<0,001$ ). The oldest patients (over 60 ) have a much higher frequency of occurrence when it comes to affective disorders than schizophrenic disorders $(32,9 \%)$ (Table 3$)$.

In the entire sample, CVC was found in 278 patients (66\%) from the schizophrenic disorder group and 143 patients (34\%) from the affective disorder group. The most frequent CVC were hypertension (53,7\% of the patients), following with CA $(19,7$ of the patients), while the less frequent disorders included IHD $(6,9 \%$ of the patients) and CMP $(2,4 \%$ of the patients).

\section{Graph 1. Frequency of CVC according to age groups of} the patients with schizophrenic disorders

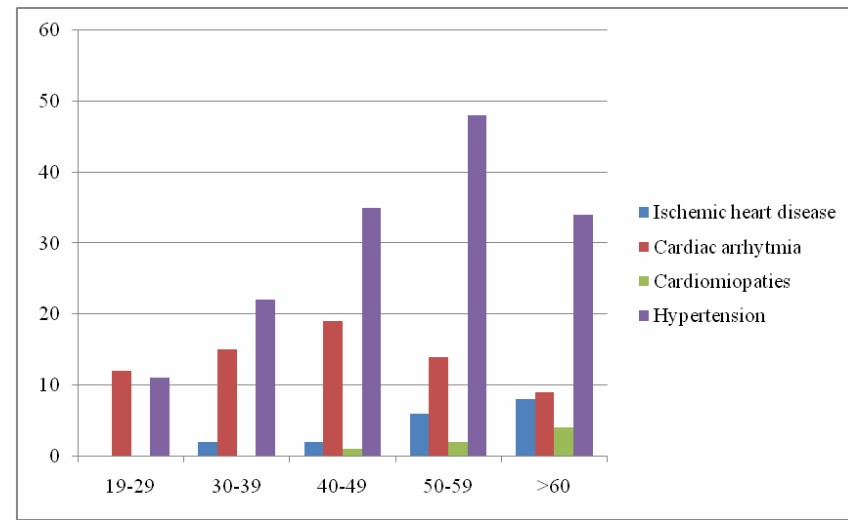

Cardiac arrhythmia have been found much more of ten $(p<0.001)$ in patients suffering from schizophrenic disorders $(24,8 \%)$ compared to patients suffering from affective disorders $(9,8 \%)$, however, significant statistical differences between the two groups of patients have not been registered regarding HTA, IHD, CMP (table 4).
Graph 2. Frequency of CVC according to age groups of the patients with affective disorders

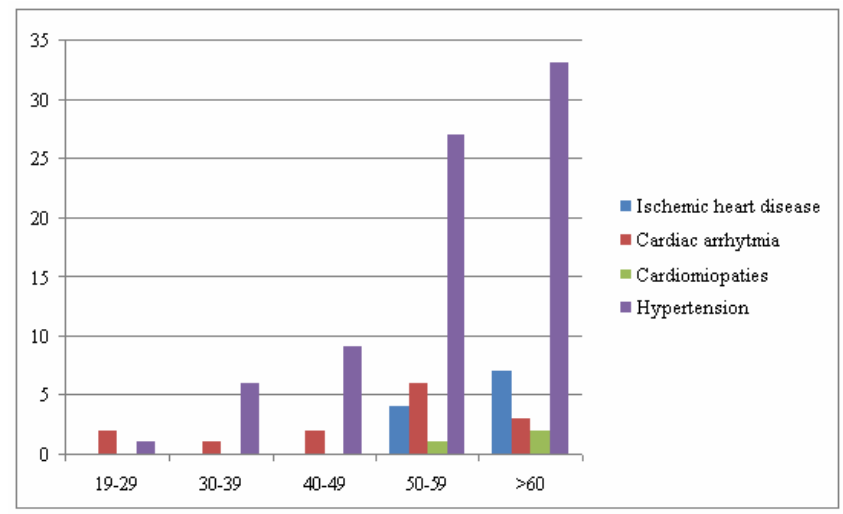

The group of patients suffering from schizophrenic disorders has shown an expectedly rising frequency of IHD with the rise of patients' ages, and IHD has most commonly been registered with the oldest patients $(44,4 \%)$. CMP has also been most frequent in the oldest of examinees $(57,1 \%)$. HTA was mostly found in patients who were $50-59$ years old $(32 \%)$ and in the oldest of examinees (22,7\%) (chi square=15,812, $D F=4, p=0.003$ ). However, the frequency of CA has been registered in a relatively equal amount with all age groups of patients who suffer from schizophrenic disorders (chi square $=6,416, D F=4, p=0.170)$ (Graph 1$)$.

IHD was most commonly registered in the oldest patients who suffer from affective disorders $(63,6 \%)$, CMP $(66,7 \%)$ and HTA $(43,4 \%)$. Cardiac arrhythmia in this group of patients were most frequent in patients between the ages of 50 and 59 (42,9\%) (Graph 2).

\section{DISCUSSION}

According to the results of this research, a significant percentage of patients from our sample has had CVC: $66 \%$ patients diagnosed with schizophrenic disorders

Table 3. Distribution of schizophrenic and affective disorders by age of the patients

\begin{tabular}{|c|c|c|}
\hline & Schizophrenic disorders & Affective disorders \\
\hline & n (\%) & n (\%) \\
\hline $19-29$ & $31(11.2)$ & $5(3.5)$ \\
\hline $30-39$ & $52(18.7)$ & $25(17.5)$ \\
\hline $40-49$ & $71(25.5)$ & $24(16.8)$ \\
\hline $50-59$ & $76(27.3)$ & $42(29.4)$ \\
\hline above 60 & $48(17.3)$ & $47(32.9)$ \\
\hline
\end{tabular}

Table 4. Distribution of CVC in examined groups of patients

\begin{tabular}{|c|c|c|c|}
\hline & $\begin{array}{l}\text { Schizophrenic disorders } \\
(n=278)\end{array}$ & $\begin{array}{l}\text { Affective disorders } \\
(n=143)\end{array}$ & p \\
\hline \multicolumn{4}{|l|}{ CMP, n (\%) } \\
\hline No & 271 (97.5) & 140 (97.9) & \multirow{2}{*}{1.000} \\
\hline Yes & $7(2.5)$ & $3(2.1)$ & \\
\hline \multicolumn{4}{|l|}{$\mathrm{CA}, \mathrm{n}(\%)$} \\
\hline No & $209(75.2)$ & $129(90.2)$ & \multirow{2}{*}{$<0.001$} \\
\hline Yes & $69(24.8)$ & $14(9.8)$ & \\
\hline \multicolumn{4}{|l|}{$\mathrm{IHD}, \mathrm{n}(\%)$} \\
\hline No & 260 (93.5) & $132(92.3)$ & \multirow{2}{*}{0.640} \\
\hline Yes & $18(6.5)$ & $11(7.7)$ & \\
\hline \multicolumn{4}{|l|}{ HTA, n (\%) } \\
\hline No & $128(46)$ & 67 (46.9) & \multirow{2}{*}{0.875} \\
\hline Yes & $150(54)$ & $76(53.1)$ & \\
\hline
\end{tabular}


and $34 \%$ patients diagnosed with affective disorders. These results are in compliance with the results of the latest researches of foreign authors $[11,12,13,14,15]$.

In the genesis of CVC in patients with severe psychiatric disorders, factors related to life habits generated by the disease itself (smoking, bad dieting, lack of physical activity, etc.) and factors related to side-effects from psychopharmacological drugs, especially the atypical ones (obesity, hyperlipidemia and diabetes mellitus) play an equally important role [16]. The explanation of the relationships between affective disorders and comorbidities of the cardiovascular system (CVS) also implies different reactions to chronic stress with multifactorial influence of the biological, psychosocial and socio-structural factors. A CVS comorbidity can be the consequence of a dysfunctional autonomous nervous system or a hypothalamic-pituitary-adrenal shaft (axle) which is present due to prolonged or chronic stress. The most important psychosocial factors are dysfunctional mechanisms of Ego defense, a greater sensibility in interpersonal conflicts, which lead to harder transcendence over interpersonal conflicts, namely reduced resilience, etc. [17]. The domination of compulsive personality traits and the need to control aggressive impulses in a socially acceptable way can likewise play a role in the creation of CVS comorbidities.

In our sample, the most commonly registered was HTS, followed by CA; while CMP and IHD occurred in a much lower number of patients. With the increase of patients' age, the frequency of occurrence of HTA, IHD and CA also increases, which is characteristic for the general population, henceforth in compliance with the result of this research.CA has been recorded in an equal great amount with schizophrenic patients across all age groups.

In both groups of examined patients, hypertension was the most frequent comorbidity. Psychoanalytically, negative emotions, such as rage, anger, tension, anxiety, if inadequately handled, can cause psychophysiological disorders of the CVS with hypertension and other cardiovascular diseases [18]. Concluded from the previous reasons, the group of patients suffering from schizophrenic disorders was expected to show a high frequency of HTA. A paranoid processing of reality can generate a high degree of aggression, hostility, enmity, hence in compliance with the previous, can lead to hypertension. A significant degree of CVC in patients with affective disorders in this study is in compliance with the results of researches by foreign authors [3, 17]. The bipolar affective disorder and the form of agitated depression both show a higher frequency in HTA and that can further be explicated by realizing that the psychiatric phenomenology, dominant in the clinical background (restlessness induced by a psychomotor, high levels of anxiety, dysphoria, etc.) can generate the previously mentioned HTA. An important statement should be made related to depressed patients, aggressiveness which is a base for the development of psychosomatic disease. This type of aggressiveness can lead to chronic hypertension, which further makes its repercussions on the functioning of the CVS. Also, the very use of atypical antipsychotics can lead to the appearance of hypertension. Antipsychotics of the second generation which most commonly lead to hypertension are clozapine, olanzapine and ziprasidone. Quetiapine and risperidone seldom cause hypertension [8].
According to the results of this research, the second most common CVC were cardiac arrhythmias. CA has been significantly more common in patients with diagnoses of schizophrenic disorders compared to patients with affective disorders. The most common disorder of heart rhythm was tachycardia. The dysfunction of the autonomous nervous system was expected in these patients, especially in phases of high anxiety and psycho-motoric agitation which generated a hauntingly hallucinatory experience. These results are in compliance with the findings of foreign authors who were researching dysfunctions of the autonomous nervous system in patients suffering from schizophrenia, especially during the phase in which positive symptoms were dominant [19]. In the group of patients suffering from schizophrenic disorders, undesired side effects of antipsychotics, incisive and atypical, can also lead to disturbed heart rhythm, and for these reasons, special caution is required when these psychopharmacological are used in combination with patients who are in an agitated state [20]. Mechanisms which have the ability to cause CA in combination with antipsychotics are their unwanted effects, a direct cardio-toxic effect or metabolic change which leads to consequential disturbance of the heart rhythm. According to data from literature, $25 \%$ of patients treated with clozapine tend to develop a persistent tachycardia with the average rise of cardiac frequency of 10-15 compared to normal values. Antipsychotics lead to prolonging of the QTC period and studies have shown that patients with a prolonged QTc period have greater risk of developing cardiac arrhythmia, especially polymorphous ventricular tachycardia - Torsades de pointes, which can be the cause of sudden cardiac death [21].

According to results from our research, the frequency of IHD did not differ in patient groups with schizophrenic and affective disorders. Numerous studies have shown the existence of a cause and effect relationship when it comes to the development of depression and IHD [6]. There are many different pathogenic mechanisms which may have significant roles in the development of IHD with depressed patients: pathophysiological mechanisms (dysfunction of the autonomous nervous system or the hypothalamic-pituitary-adrenal axis, an increased activation of the sympathetic-adrenaline system, inflammation, endothelial dysfunction and genetic predisposition), behavioral mechanisms (inadequate therapeutic adherence, obesity, smoking, inadequate lifestyle with a lot of inactivity and a poor physical activity) [17]. Coronary disease is a common disease in depressed patients who feel inferior, who have frustrated ambitions and who are exposed to chronic stress due to the impossibility to achieve their ambitions. Chronic stress leads to heightened secretion of catecholamine and it rises the level of cholesterol in the serum, which has significance in the genesis of coronary disease $[18,22]$. When choosing the suitable antidepressant, one should have in mind that tricyclic antidepressants have unwanted side effects on the CVS. It is a good thing that today, in modern protocols for medical treatment of depression, the most common drugs are SSRI which are safer for use with patients with cardiac disease [17,20,22]. A possible explanation for the absence of differences in frequency of IHD in patients suffering from schizophrenic and affective disorders in our research lay in the more frequent use of SSRI on patients who suffer from depression.. 


\section{CONCLUSION}

The results of this research confirm a high degree of CVC in hospitalized patients diagnosed with schizophrenic and affective disorders (especially CA and HTA). CA more commonly appears in the group of patients who suffer from schizophrenic disorders and taking into consideration the possibility that malign heart rhythm disorders could develop, said patients require a strict electrocardiographic monitoring and evaluation. A multidisciplinary team is key in order to correctly diagnose and monitor patients with schizophrenic and affective disorders, both in primary and secondary prevention.

\section{REFERENCES}

1. De Hert M, Correll HU, BoBes J, Cetkovich-Bakmas M, Cohen D, Asai I. et al. Physical illness in patients with severe mental disorders. I. Prevalence, impact of medications and disparities in health care. World Psychiatry, 2011; 10:52-77.

2. Gardner-Sood P, Lally J, Smith S, Atakan Z, Ismail K, Greenwood KE et al. Cardiovascular risk factors and metabolic syndrome in people with established psychotic illnesses: baseline data from the IMPaCT randomized controlled trial. Psychological Medicine, 2015; 45, 2619-29.

3. The Robert Wood Johnson Foundation, Research Synthesis Report No. 21.Mental disorders and medical comorbidity, 2011

4. Ignaszewski MJ, Yip A, Fitzpatrick S. Schizophrenia and coronary artery disease. BCMJ, 2015; 57(4):154-7.

5. Ringen PA, Engh JA, Birkenaes AB, Dieset I, Andreassen OA. Increased Mortality in Schizophrenia Due to Cardiovascular Disease A Non-Systematic Review of Epidemiology, Possible Causes, and Intervention. Front Psychiatry, 2014; 5: 137. doi: $10.3389 /$ fpsyt.2014.00137

6. Musselman DL, Evans DL, Nemeroff CB. The Relationship of Depression to Cardiovascular Disease.Epidemiology, Biology, and Treatment. Arch Gen Psychiatry. 1998; 55:580-92

7. Girardin F. Cardiac adverse reactions associated with psychotropic drugs. Dialogues Clin Neurosci, 2007; 9(1): 92-5.

8. Fadi T. Khasawneh and Gollapudi S. Shankar, "Minimizing Cardiovascular Adverse Effects of Atypical Antipsychotic Drugs in Patients with Schizophrenia," Cardiology Research and Practice, vol. 2014, Article ID 273060, 8 pages, 2014. doi: $10.1155 / 2014 / 273060$

9. De Hert M, Dekker JM, Wood D, Kahl KG, Holt RI, Möller HJ. Cardiovascular disease and diabetes in people with severe mental illness position statement from the European Psychiatric Association (EPA), supported by the European Association for the Study of Diabetes (EASD) and the European Society of Cardiology (ESC). Eur Psychiatry. 2009; 24(6):412-24.

10. Smith DJ, Martin D, McLean G , Langan J, Guthrie B, Mercer SW. Multimorbidity in bipolar disorder and under treatment of cardiovascular disease: a cross sectional study. BMC Med. 2013; 11:263. doi: 10.1186/1741-7015-11-263.

11. Beutel ME \& Schulz H. Comorbid psychological disorders in patients with chronic somatic diseases. Bundes. Gesund. Geseund. 2011; 54(1): 15-21.

12. Juckel G. Psychiatric disorders and their effects on mortality and morbidity. Versicherungsmedizin. 2014; 66(4): 184-7.

13. Friedrich $\mathrm{F}$, Litvan Z, Freidl M. Comorbid somatic illness in psychiatric inpatiens- an analiysis of administrative data. Neuropsychiatr. 2015; 29 (2):71-6.

14. Holt R. The prevention of diabetes and cardiovascular disease in people with schizophrenia. Acta Psychiatr Scand. 2015; 132(2):86-96.

15. Munoz-Calero Franco P, Sanchez Sanchez B, Rodriguez Criado N, et al. Metabolic syndrome and cardiovascular risk in patients with schizophrenia, bipolar disorder and schizoafective disorder. Nutr hosp. 2015; 32(6): 2715-7.

16. Lambert TJR, Velakoulis D, Pantelis C. Medical comorbidity in schizophrenia. MJA 2003; 178: 67-70.

17. Pizzi C, Santarella L, Manfrini O, Chiavaroli M, et al. Ischemic heart disease and depression: an underestimated clinical association. G Ital Cardiol (Romme).2013; 14(7-8): 526-37.

18. Marić J. Klinička psihijatrija- XI prerađeno i dopunjeno izdanje. Beograd: Megraf; 2005.

19. Bar KJ. Cardiac autonomic dysfunction in patients with schizophrenia and their healthy relatives- a small review. Front Neurol.2015; 6:139.

20. Stahl SM. The Prescriber's Guide. Stahl's Essential Psychopharmacology. Third Edition. Cambridge University Press, 2009.

21. Graylands Hospital Drug Bulletin. Cardiac Adverse Effects of Psychotropic Medication in Schizophrenia. North Metropolitan Area Mental Health Service November 2010 Volume 2 ISSN 1323-125110 (assessed online on April, 10th, 2016)

22. Dukić-Dejanović S, urednik. Psihijatrija. Kragujevac: Medicinski fakultet Univerziteta u Kragujevcu; 2011. 


\section{SRPSKI}

\section{KARDIOVASKULARNI KOMORBIDITETI KOD HOSPITALNO LEČENIH PSIHIJATRIJSKIH PACIJENATA IZ DIJAGNOSTIČKIH KATEGORIJA SHIZOFRENIH I AFEKTIVNIH POREMEĆAJA}

Djokić Pješčić Katarina ${ }^{1,2}$, Gutović Jasmina ${ }^{1}$, Tesić Jelica ${ }^{1}$, Đukić Dejanović Slavica ${ }^{1,3}$, Grbić lgor ${ }^{1,2}$, Cvetković Jovana ${ }^{2}$

1 Klinika za psihijatrijske bolesti „Dr Laza Lazarević“, Beograd, Srbija

${ }^{2}$ Medicinski fakultet Univerziteta u Prištini, Kosovska Mitrovica, Srbija

${ }^{3}$ Medicinski fakultet Univerziteta u Kragujevcu, Srbija

\section{SAŽETAK}

Kardiovaskularni komorbiditet (KVK) kod psihijatrijskih bolesnika predstavlja istovremenu pojavu kardiovaskularne i mentalne bolesti kod istog pacijenta bez obzira na redosled javljanja ili uzročno posledični odnos koji ih povezuje. Cilj ovog rada bio je da utvrdi frekventnost i vrste KVK kod hospitalno lečenih pacijenata iz dijagnostičkih kategorija shizofrenih i afektivnih poremećaja, kao i razlike u distribuciji ovih poremećaja u ove dve grupe bolesnika. Po dizajnu ovo je retrospektivna studija preseka. Bazirana je na analizi medicinske dokumentacije (istorija bolesti sa protokolom internističkih pregleda) hospitalno lečenih pacijenata u Klinici za psihijatrijske bolesti „, Dr Laza Lazarević“ u Beogradu u periodu od novembra 2014.godine do februara 2015.godine. Uključeni su pacijenti stariji od 18 godina sa diganozama shizofrenih poremećaja (F20-F29) i afektivnih poremećaja (F30-F39), prema dijagnostičkim kriterijumima Međunarodne klasifikacije bolesti 10 (MKB-10). KVK koji su bili dijagnostikovani ranije ili registrovani pri pregledu, bili su podeljeni u sledeće grupe prema MKB-10: hipertenzija (HTA) 110, poremećaji srčanog ritma (PSR) 147-149, hronična kardiomiopatija (CMP) I42-I43 i ishemijska bolest srca (IBS) 120-125. Analizirane su razlike u dve grupe bolesnika u odnosu na sociodemografske karakteristike (pol i starosna dob) i KVK dijagnostikovane prema MKB-10 klasifikaciji. KVK su registrovani kod $66 \%$ pacijenata iz grupe shizofrenih i $34 \%$ pacijenata iz grupe afektivnih poremećaja. Hipertenzija je bila najzastupljenija u obe grupe pacijenata, a potom su sledeli poremećaji srčanog ritma. PSR su se statistički značajno češće javljali u grupi pacijenata sa shizofrenim poremećajima $(p<0.001)$ u odnosu na pacijente sa afektivnim poremećajima. Učestalost HTA, IBS i CMP je u obe grupe rasla sa starošću pacijenata. Rezultati ovog istraživanja potvđuju visok stepen KVK kod hospitalno lečenih pacijenata iz dijagnostičkih kategorija shizofrenih i afektivnih poremećaja (posebno PSR i HTA). Multisciplinarni tim je ključna karika za dijagnozu i praćenje pacijenata sa shizofrenim i afektivnim poremećajima, kako u primarnoj, tako i u sekundarnoj prevenciji.

Ključne reči: komorbiditet, KVS oboljenja, shizofreni poremećaji, afektivni poremećaji 